\title{
Dietary Intake of Tribal Women of Reproductive Age Group of Meghalaya, India
}

\author{
Elvina Shongsir Monsang and Namita Singh*
}

Department of Food Science and Nutrition, College of Home Science, CAU (Imphal), Tura, Meghalaya, India

*Corresponding author

\section{A B S T R A C T}

\begin{tabular}{|l|}
\hline Ke y w o r d s \\
$\begin{array}{l}\text { Dietary intake, RDA, } \\
\text { Tribes, Reproductive age, } \\
\text { Meghalaya }\end{array}$ \\
\hline Article Info \\
\hline $\begin{array}{l}\text { Accepted: } \\
15 \text { September } 2018 \\
\text { Available Online: } \\
10 \text { October } 2018\end{array}$ \\
\hline
\end{tabular}

\section{Introduction}

Nutritional status indicates health status. It can be assessed by the intake of balanced diet and the body's ability to digest, absorb and use those nutrients. A balanced diet is required for proper growth and development from the early stages of life. Healthy baby can be born from women of good nutritional status (Goswami and Bhattacharyya, 2015). Diet and nutrition play an important role for proper functioning and maintenance of good health throughout the life. A balanced diet must contain various food groups in adequate amounts to meet the needs of an individual and to increase immunity (Mittal, 2013). Improper health and dietary intake in women of reproductive age can result in deficiency of several essential nutrients. Adequate nutritional status and proper dietary intake pattern of women improves maternal and child health (Wani and Jan, 2016). Food habits effect nutritional status therefore is necessary to assess the tribal food habits because a particular tribe food habits differ to another tribe and also from one region to another (Joshi and Singh, 2015). In Meghalaya, majority is non-vegetarians, follow two meal patterns and do not have any food beliefs or taboos (Rynjah et al., 2009). Calorie consumption is very low in Meghalaya. Meghalaya spends a lower percentage in the consumption of pulses and pulse products, milk and milk products and a higher percentage on egg, fish and meat, paan, 
supari, etc. (Shadap and Pala, 2017). With all efforts for the upliftment of the oppressed class, there still exists large variation in different caste groups and SC/ST people today who are at the most disadvantageous position (Mishra et al., 2011). Therefore, the present study was conducted with the objective to assess dietary intakes of subjects in terms of quantity and quality.

\section{The tribes of Meghalaya}

In Meghalaya, three major tribes, Khasi, Garo and Jaintia are visible, who have different cultures, norms, taboos, customary laws, languages etc (Lahiri and Das, 2010). Besides that several other minor tribal and sub-tribal groups like Hajong, Koch, Banai, Bodo, Rabha etc. are also living here for a long time (Samajdar et al., 2016).

The Garo people call themselves AChik meaning hillmen. By stature they are of medium height, strong built and dark skinned. The Garo society follow matrilineal pattern. The children take the title of the mother and the selected daughter inherits the parental properties; in most cases the youngest one. The main occupation of Garos is basically agriculture. Rice is a main cereal crop. Majority of the households in the village rear pig and chicken, some have goats and cows. The people collect fire-wood, bamboo and shrubs from the forest. Garo people are cheerful and sociable in nature. Garo society is matrilineal, and inheritance is through the mother. In Garo hills, the land is of two types; a king and amilam land. The management of the aking land is entrusted to the Nokma or Village Headman. Nokma is the husband of the main lady of the founder clan (Machong) of the community. The District Council possesses complete records of the boundaries of each tract of an $a$ king land and handover to Nokma. Nokma distributes his aking land among the individual farmer for a particular period for cultivation purpose. The individual need is not to pay any tribute to the Nokma. Obviously, Nokma has very important role in agriculture in Garo Hills, because he has the sole authority to distribute the land to the villagers and also provides some directions (Kar, 1982; Lahiri and Das, 2010).

The Khasi people are usually short in stature and the skin colour vary from dark to a light yellowish brown, yellow skin and fair complexion. The Khasi ladies wear Jainsem, a two piece cloth pinned up at the shoulder by clips. The Jaintia people are generally short and sturdy people. They call themselves Pnar. The Jaintias wear one long piece of fabric pinned up only on one side of the shoulder in everyday wear. Like the Garo, the Khasi and Jaintia, children also take the title of the mother.

\section{Materials and Methods}

This research paper is a part of Post Graduate research conducted by the student before starting the data collection the study was presented in front of Institutional Ethical Committee (IEC) and ethical clearance was taken.

It was a cross sectional study conducted in five villages of three districts of Meghalaya among 150 randomly selected reproductive age group tribal women. Figure 1 shows district map of Meghalaya. Among the eleven districts in Meghalaya, West Garo Hills district, Ri- Bhoi district and West Jaintiya Hills district were selected purposively for the study to cover three major tribal groups (Garo, Khasi and Jayantia) and easy accessibility of the researcher. The villages were selected by stratified random sampling technique. Women of reproductive age group i.e. 15-49 years were considered as unit of study. Female with at least one child below 5 years of age was eligible to be study subject. Personal interview 
method was used by the researchers to obtain the relevant data on various aspects. The twenty four hours recall method was used for diet survey to assess the dietary food intakes. Dietary intake information was collected by interviewing the subjects. Standardized utensils (e.g. bowls for measuring rice, dal, vegetables, etc., spoons for measuring oil, sugar etc.) was used for measuring the approximate intake of different food items along with a small weighing machine to get more accurate results. Appropriate statistical analyses namely frequency and percentage distribution, mean distribution, range, standard deviation etc. were included wherever required. Dietcal software was used for dietary analysis and Microsoft Excel was used for statistical analyses.

\section{Results and Discussion}

The research findings of the present study are discussed under the following heads:

\section{Per capita income}

Table 1 shows the subjects per capita income. Majority $(29.33 \%)$ of the subjects per capita income was Rs. $>3000$, followed by per capita income of Rs.1500-2000 (22\%), Rs.10001500 (20\%) and Rs. 2500-3000 (12.67\%). Only 8.67 per cent and 7.33 per cent had per capita income of Rs. $<1000$ and Rs. 20002500 respectively.

\section{Dietary intake (24 hours recall method)}

Figures 2-6 shows the dietary intake of the subjects. Majority of the subject dietary intake were less than the recommended dietary allowance (RDA, 2010) as it is observed in the study. Figures 7-11 shows district wise intake of energy, protein, fat, iron and calcium of the subjects. The estimated RDA of energy is $1900 \mathrm{kcal} / \mathrm{d}$ (sedentary work), 2230kacl $/ \mathrm{d}$ (moderate work), 2850kcal/d (heavy work) and protein $55 \mathrm{~g} / \mathrm{d}$, fat $20 \mathrm{~g} / \mathrm{d}$ (sedentary work), $25 \mathrm{~g} / \mathrm{d}$ (moderate work), 30g/d (heavy work), calcium $600 \mathrm{mg} / \mathrm{d}$ and iron $21 \mathrm{mg} / \mathrm{d}$ respectively. The mean intake of energy, Protein, fat, iron and calcium were 1739.11 $\pm 273.37 \mathrm{kcal}$ (range 1123.23 - $2542.66 \mathrm{kcal}$ ), $34.78 \pm 23.35 \mathrm{~g}$ (range $25.19-60.77 \mathrm{~g}), 40.13$ $\pm 20.56 \mathrm{~g}$ (range $13.75-58.06 \mathrm{~g}$ ), $5.19 \pm 2.36 \mathrm{mg}$ and $134.29 \pm 69.52 \mathrm{mg}$ respectively (Table 2 ). The intake of energy, protein as well as both calcium and iron intake of the subjects did not meet the daily RDA. However intake of fat was found higher than the daily RDA in majority of the subjects. About the energy intake, 16 per cent had energy intake of below $1500 \mathrm{kcal}, 36$ per cent had energy intake of between $1500-1800 \mathrm{kcal}, 17.33$ per cent had energy intake of between 1800-1900 kcal, 16 per cent had energy intake of between 1900$2000 \mathrm{kcal}$ and 14.67 per cent had energy intake of above $2000 \mathrm{kcal}$ respectively.

Majority $(50.67 \%)$ of the study women protein intake were below 35g. About one fifth $(22.67 \%)$ of the subjects protein intake was between 35 to $45 \mathrm{~g} .15 .33$ per cent and 11.33 per cent of the subjects had protein intake of 45 to $55 \mathrm{~g}$ and above $55 \mathrm{~g}$ respectively. Only 5.33 per cent of the subjects' fat intake was below $20 \mathrm{~g}, 26$ per cent intake was between 20 to $30 \mathrm{~g}$, intake between 30 and $40 \mathrm{~g}$ was 34 per cent and above $40 \mathrm{~g} 34.67$ per cent respectively. Calcium intake of the subjects was below $100 \mathrm{mg}$ (42\%), between 100 to $200 \mathrm{mg}$ was 33.34 per cent, between 200 to $300 \mathrm{mg}$ was 17.33 per cent and above $300 \mathrm{mg}$ was 7.33 per cent respectively. Majority of the subjects iron intake were below $5 \mathrm{mg}$ $(44.67 \%)$, intake between 5 to $10 \mathrm{mg}$ was 42.67 per cent and above $10 \mathrm{mg}$ was 12.66 per cent respectively. The deficiency in the dietary intake of the subjects would increase the risk of malnutrition among the population. The deficiency of iron intake of the study tribal women can increase the risk of iron deficiency anaemia. 


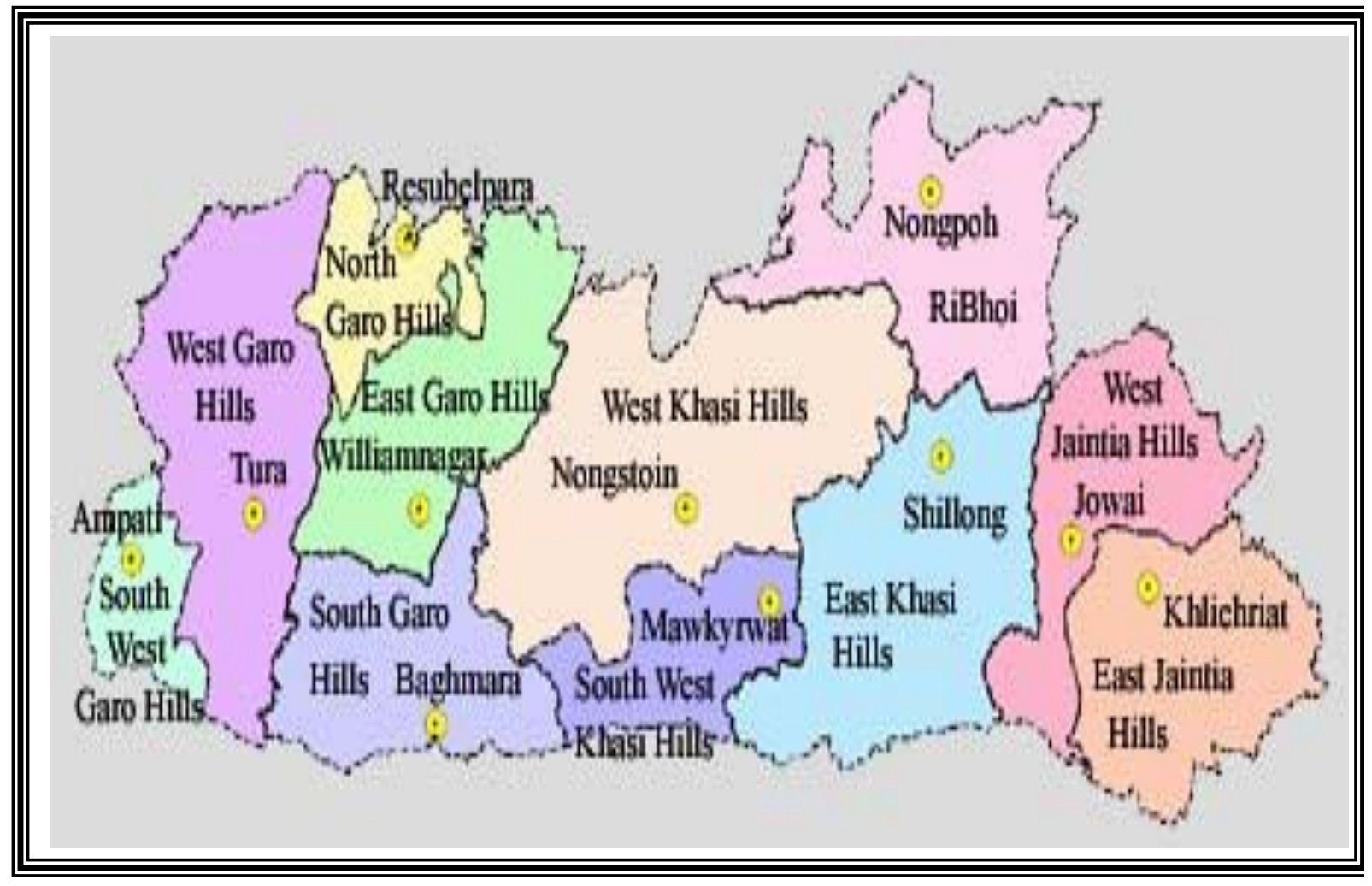

Fig. 1 District Map of Meghalaya
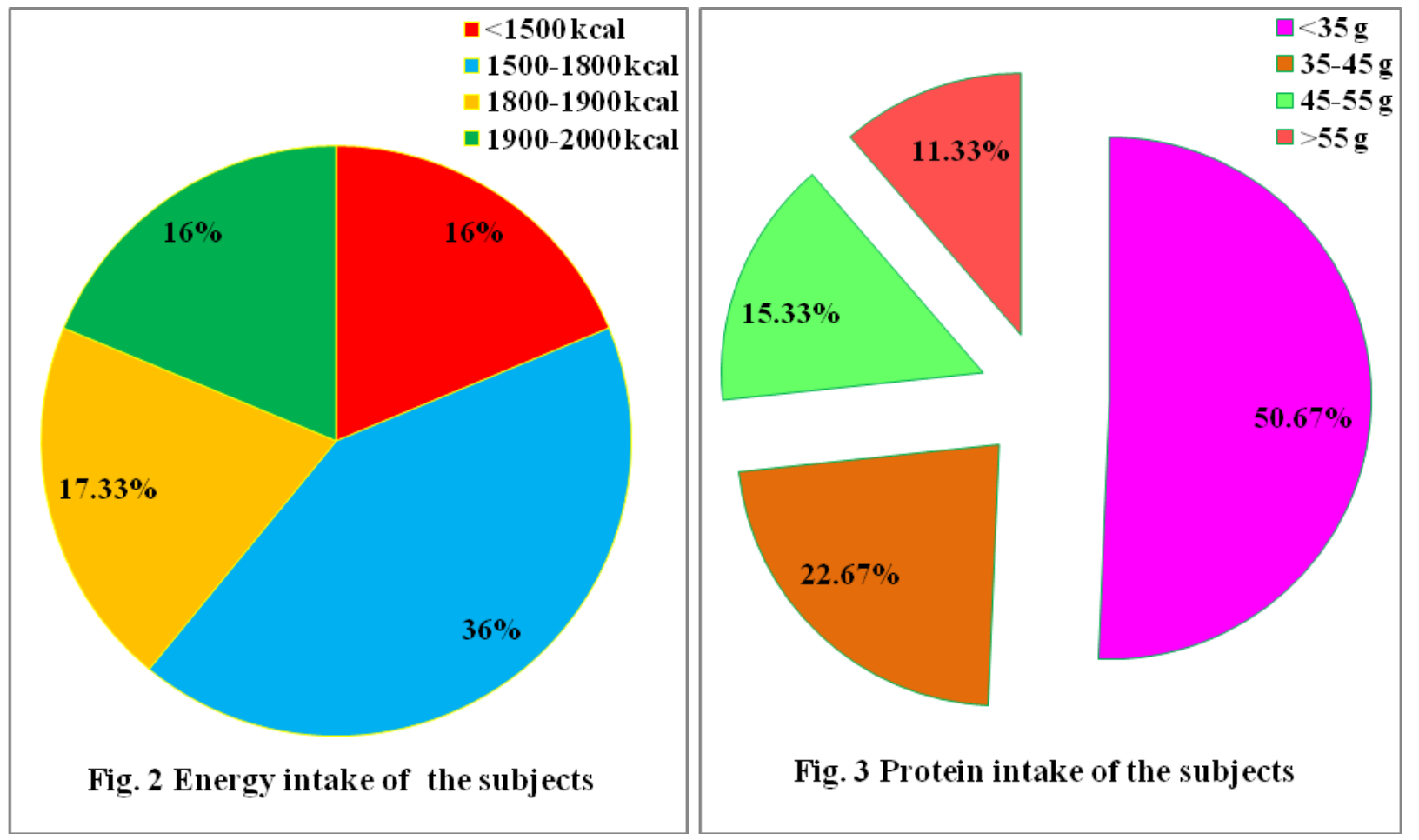
Int.J.Curr.Microbiol.App.Sci (2018) 7(10): 1847-1855
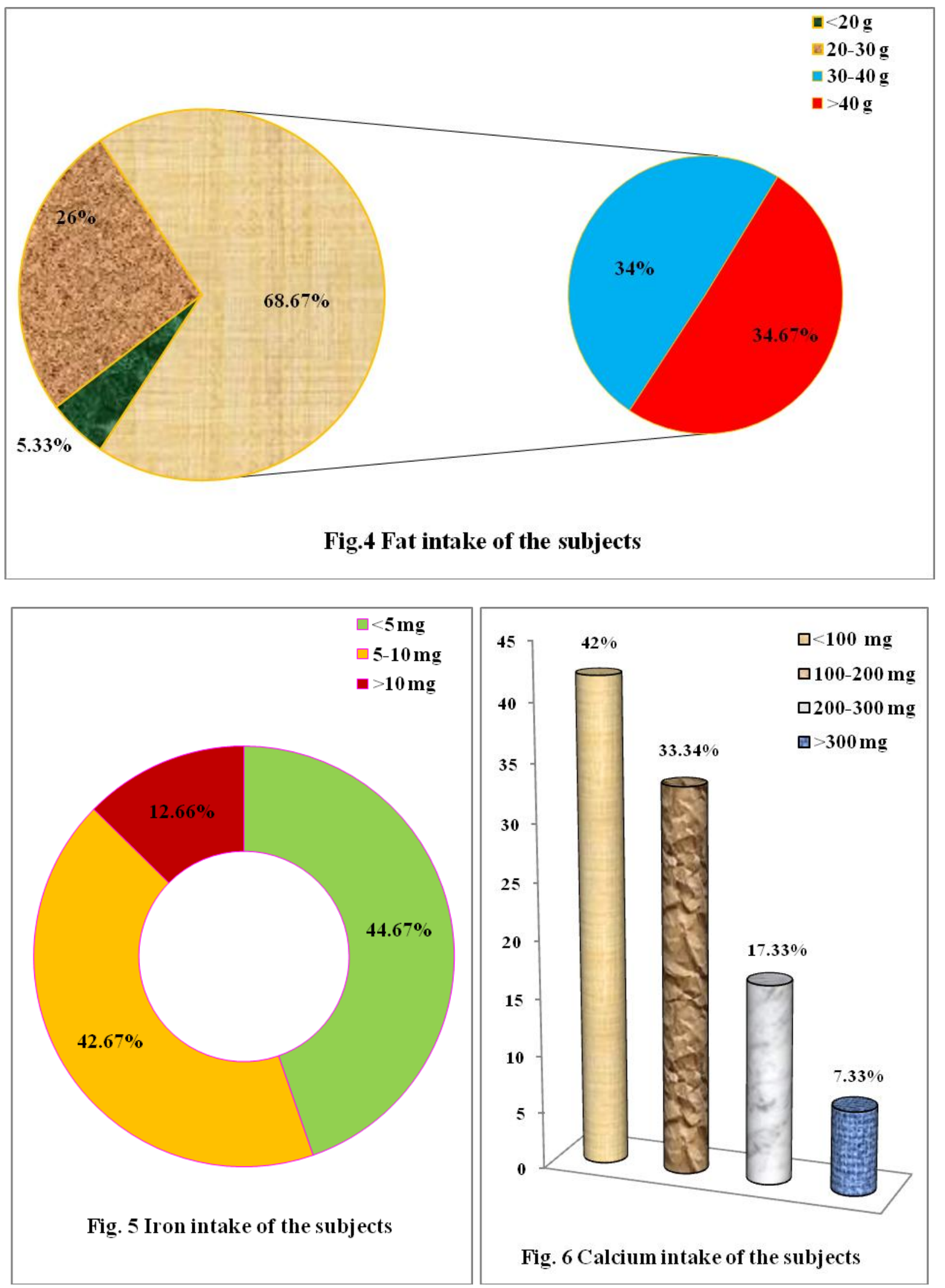

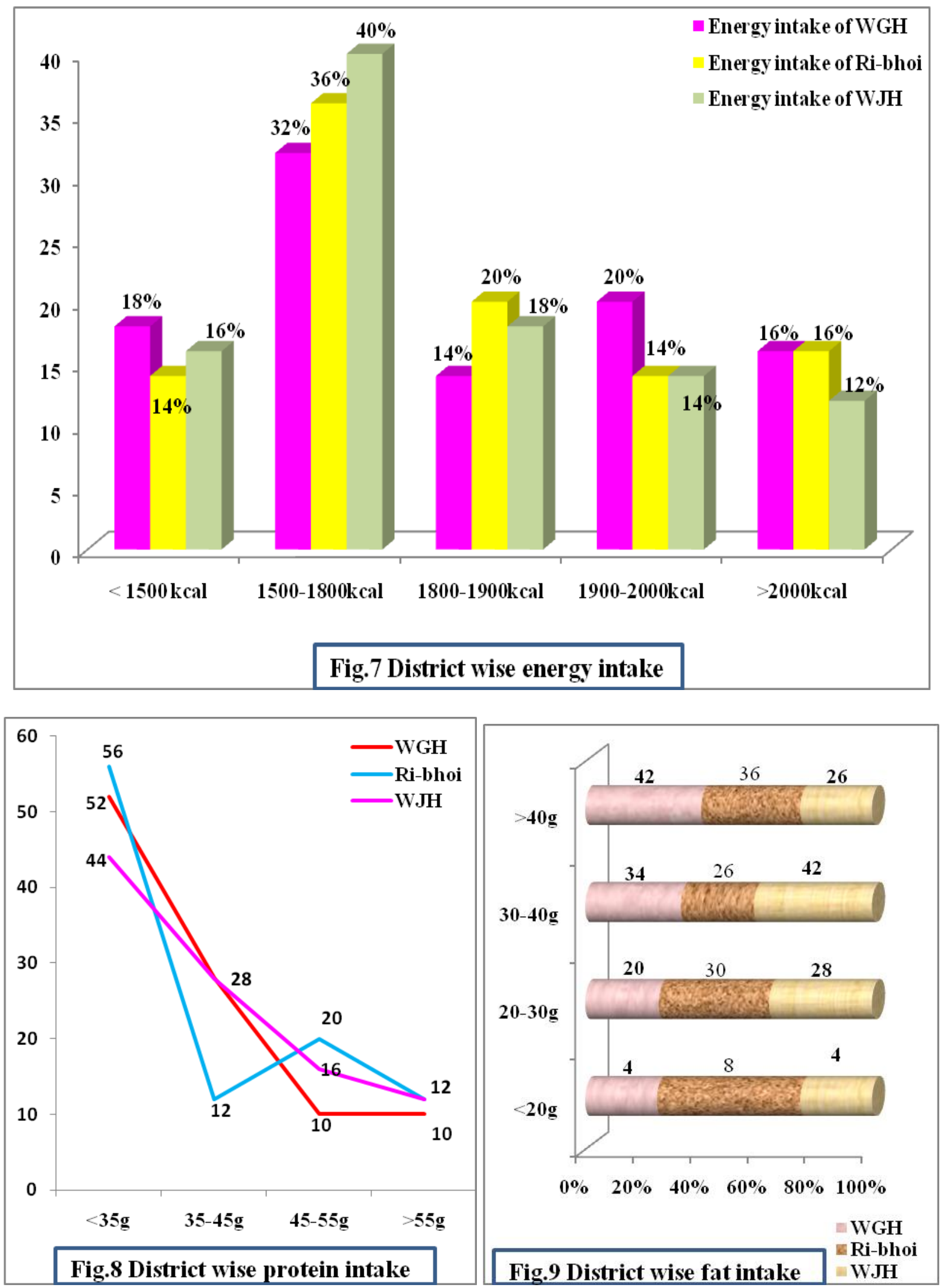

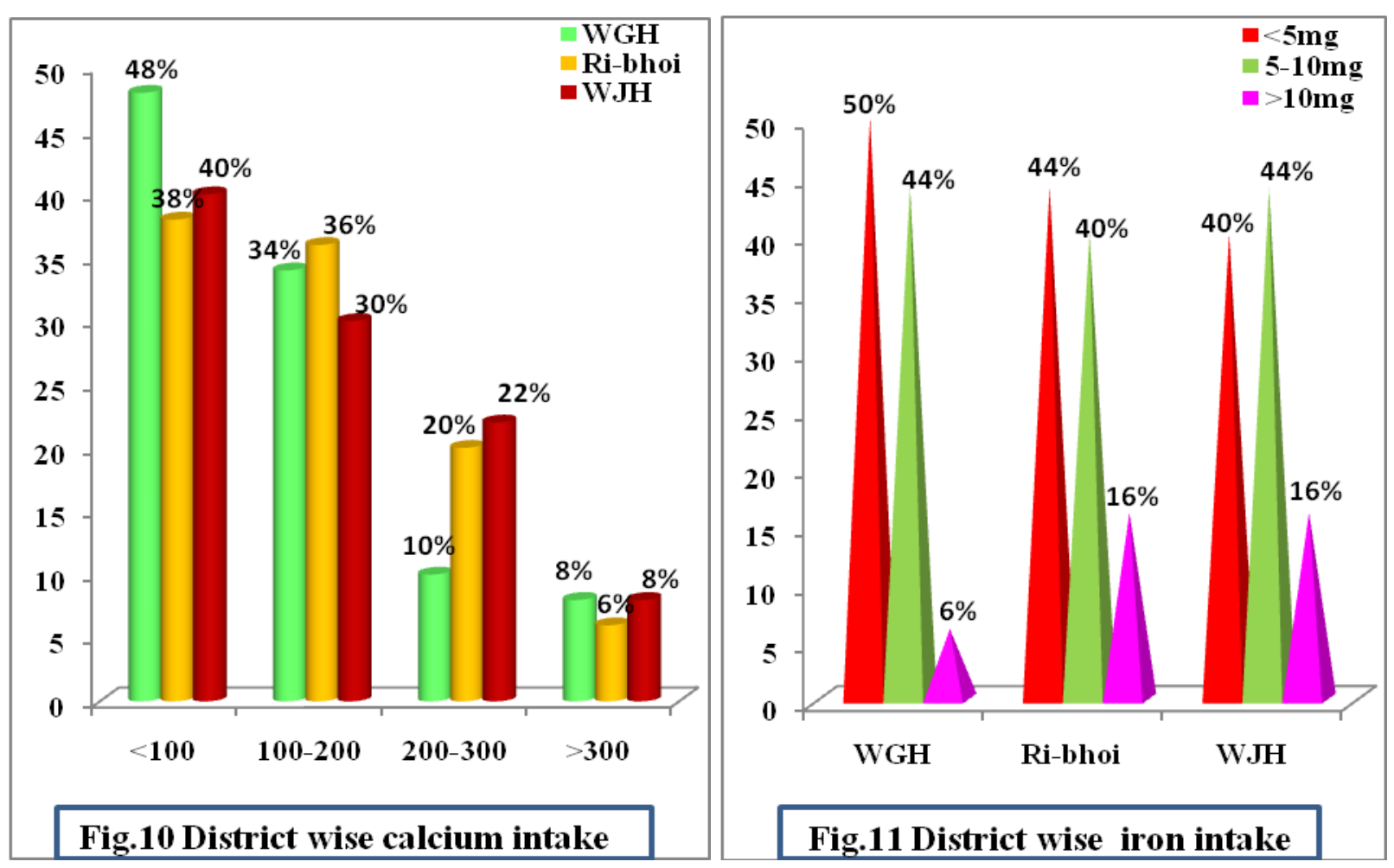

\begin{tabular}{|l|c|c|}
\hline \multicolumn{3}{|c|}{ Table.1 Distribution of the subjects according to their per capita income (in rupees) } \\
\hline Per capita income & Frequency & Per cent \\
\hline$<\mathbf{1 0 0 0}$ & 13 & 8.67 \\
\hline $\mathbf{1 0 0 0}$ to $\mathbf{1 5 0 0}$ & 30 & 20.0 \\
\hline $\mathbf{1 5 0 0 - 2 0 0 0}$ & 33 & 22.0 \\
\hline $\mathbf{2 0 0 0 - 2 5 0 0}$ & 11 & 7.33 \\
\hline $\mathbf{2 5 0 0 - 3 0 0 0}$ & 19 & 12.67 \\
\hline $\mathbf{3 0 0 0}$ & 44 & 29.33 \\
\hline Total & $\mathbf{1 5 0}$ & $\mathbf{1 0 0}$ \\
\hline
\end{tabular}

\section{Table.2 Mean distribution, standard deviation of dietary intake of the subjects}

\begin{tabular}{|l|}
\hline Nutrient \\
\hline Energy \\
\hline Protein \\
\hline Fat \\
\hline Iron \\
\hline Calcium
\end{tabular}

\begin{tabular}{|c|c|}
\hline Mean & S.D. \\
\hline 1739.11 & 273.37 \\
\hline 34.78 & 23.35 \\
\hline 40.13 & 20.56 \\
\hline 5.19 & 2.36 \\
\hline 134.29 & 69.52 \\
\hline
\end{tabular}

Table.3 Relationship between per capita income and dietary intake

\begin{tabular}{|l|l|c|c|c|}
\hline Sl. No. & Parameters & \multicolumn{3}{|c|}{ Dietary intake } \\
\cline { 3 - 5 } & & Energy $(\mathrm{kcal})$ & Protein $(\mathrm{g})$ & Fat $(\mathrm{g})$ \\
\hline 1. & Per capita income & +0.92 & +0.58 & +0.49
\end{tabular}


Similarly, Shadap and Pala (2017) reported the lowest calorie intake per person per day with substantial decline in the consumption of protein in Meghalaya compared to the recommended requirement. However, in case of consumption of fat, it is above the normative requirement. Mittal (2013), Rao and Sugunan et al., (2006), Kaur and Kaur (2011), Nanda and Dhar (2017) and Wani and Jan (2016) had also reported the dietary intake of the tribal women lower than the RDA.

\section{Relationship between per capita income and dietary intake}

Table 3 depicts the coefficient of correlation (r) between per capita income and dietary intake. It is clear from the table that per capita income was positively correlated with dietary intake i.e. dietary intake of the subjects' increases with increase per capita income.

This study depicted a clear picture of dietary intake of tribal females of reproductive age group of Meghalaya. It revealed that the dietary intakes of the tribal women of reproductive age groups were in a critical state. This could increase the risk of under nutrition as well as nutrient deficiency diseases because nutritional status is directly connected with the dietary habits. It also revealed that consumption of protein, calcium and iron are inadequate. However the consumption of fat is above the RDA, which may lead to unwanted obesity. Thus, it can be concluded that there is a need to formulate appropriate strategies and meticulous planning for improvements in nutrition for improving the dietary intake as well as energy balance among parents and community members.

\section{References}

Goswami, R., and Bhattacharyya, M. (2015). Nutritional status among adult Karbi women of Kamrup District Assam. Int. Res. J. Social Sci., 4 (9): 17-20.

Joshi, S., and Singh, V. (2015). Assessment of food related habits and customs of Bhil tribe of Udaipur district, Rajasthan. Food sci. Res. J., 6 (2): 333-340.

Kar, P. C. (1982). The Garos in Transition. publ: Cosmo Publications, New Delhi. Pp-22-32, 44-61.

Kaur, I.P., and Kaur, S. (2011). A comparison of nutritional profile and prevalence of anemia among rural girls and boys. $J$. Exercise Sc. Physioth., 7 (1): 11-18.

Lahiri, B. and Das, P. (2010). Role of nokma (village headman) in agriculture of West Garo Hills, Meghalaya. J. Exten. Edu., 15 (1\&2): 72-82.

Mishra, C.P., Yadav, S., and Srivastava P. (2011). Energy balance Vis- $\mathrm{A}-\mathrm{Vis}$ nutritional status of rural reproductive age group females of Azamgarh District, Uttar Pradesh. Indian J. Prev. Soc. Med., 42 (3): 329- 334.

Mittal, M. (2013). To assess the nutritional status and morbidity patterns among non-pregnant non-lactating rural women of reproductive age group (18-40 Years). Int. J. Sci. Res. Pub., 3 (9):1-47.

Nanda, S., and Dhar, R. N. (2017). A study on nutritional status of adolescent girls of Dongria Kondh tribe. Int. J. Community Med. Pub. Health, 4 (5): 1573-1576.

Rao, V.G., Sugunan, A.P., Murhekar, M.V., and Sehgal, S.C. (2006). Malnutrition and high childhood mortality among the Onge tribe of the Andaman and Nicobar Islands. Pub. Health Nutr., 9 (1): 19-25.

Rynjah, R., Anuradha, V., and Thilagamani, S. (2009). Nutritional status of tobacco users among the khasi tribes in Meghalaya. Indian J. Nutr. Dietet., 46 (9): 357-363.

Samajdar, T., Das, T. K. and Lahiri, B. (2016). Knowledge, attitude and practices of different tribes of Garo Hills districts of Meghalaya towards 
scientific horticulture. J.KrishiVigyan, 4 (2): 58-65.

Shadap, A.M.W. K., and Pala, V. (2017).

Nutritional Intake and Consumption Pattern in the States of Himachal Pradesh and Meghalaya. The NEHU J., 15 (2):15-28.
Wani, M., and Jan, S. (2016). A study on nutritional and health status of adult Gujjar women of Bandipora district of Kashmir. Int. J. Home Sc., 2 (3): 332335.

\section{How to cite this article:}

Elvina Shongsir Monsang and Namita Singh. 2018. Dietary Intake of Tribal Women of Reproductive Age Group of Meghalaya, India. Int.J.Curr.Microbiol.App.Sci. 7(10): 1847-1855. doi: https://doi.org/10.20546/ijcmas.2018.710.212 